\title{
Morrison v. National Australia Bank and the Future of Extraterritorial Application of the U.S. Securities Laws
}

\author{
GENEVIEVE BEYEA*
}

In recent years securities markets have become increasingly interconnected, and securities fraud frequently crosses borders. The United States' welldeveloped private enforcement mechanism for securities fraud is very attractive to investors around the world who are harmed by transnational securities fraud. However, the Supreme Court's recent decision in Morrison v. National Australia Bank, in overturning nearly fifty years of federal court jurisprudence, severely limits the ability of investors to rely on the U.S. securities laws to protect them when the relevant fraud has a significant overseas component. Replacing the Second Circuit's long-standing conduct and effects tests for determining the extraterritorial reach of the securities laws, the Supreme Court articulated a new transactional test for when the laws apply. This Article analyzes the Supreme Court's opinion and its implications for the regulation of transnational securities fraud. It also examines certain provisions of the Dodd-Frank Act which attempted to overturn the Supreme Court's decision as it applies to securities fraud enforcement actions brought by the Securities and Exchange Commission. Ultimately, this Article argues that the Morrison decision significantly curtails the extraterritorial application of the securities laws, which may harm investor confidence, at least in the short term. However, it also has the potential to encourage greater international cooperation in regulating transnational securities fraud, as well as catalyzing regulatory reform in other countries.

\section{TABLE OF CONTENTS}

I. INTRODUCTION

II. EXTRATERRITORIAL APPLICATION OF THE U.S. SECURITIES ANTIFRAUd RULES PRIOR TO MORRISON V. NATIONAL AUSTRALIA $B A N K$

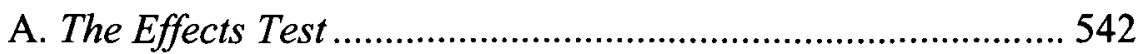

B. The Conduct Test .................................................................. 543

* Assistant Professor, Texas Tech University School of Law; J.D., New York University School of Law; B.A., Northwestern University. The author would like to thank: various faculty members at Texas Tech University School of Law for listening to and providing feedback on "half-baked" research ideas; Professor Linda Silberman of NYU School of Law for my early education in extraterritorial application of U.S. law and for sparking my interest in the area; Thomas Vita and Michael Dunn of Norton Rose LLP in London for my initial education in American Depositary Receipt programs. 
C. Application of Section 10(b) in Foreign-Cubed Cases .......... 544

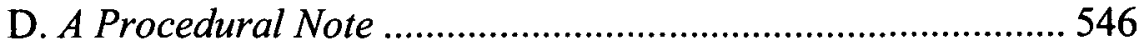

III. MORRISON V. NATIONAL AUSTRALIA BANK ...................................547

A. Morrison v. National Australia Bank in the Lower Courts.... 547

B. The Supreme Court Opinion ............................................... 550

IV. IMPLICATIONS OF THE SUPREME COURT DECISION FOR REGULATION

OF TRANSNATIONAL SECURITIES FRAUD ......................................553

A. Uncertainty, Jurisdictional Conflict, and International

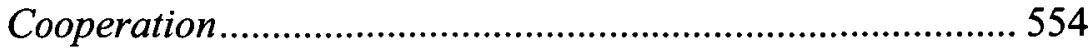

B. The Supreme Court Embraces a Transaction-Based Test ..... 558

C. Implications of the Court's Opinion on Specific Constituencies: Dual-and Cross-Listed Companies and U.S. Investors Purchasing Shares in Foreign Companies............................. 562

V. CONGRESSIONAL AND REGULATORY RESPONSES TO MORRISON ....570

A. The Dodd-Frank Act ....................................................... 570

B. Possible Securities and Exchange Commission Responses to Morrison v. National Australia Bank .................................... 572

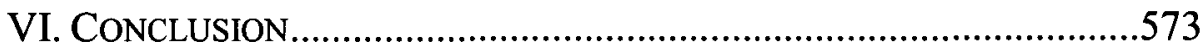

\section{INTRODUCTION}

"This appeal requires us to revisit the vexing question of the extraterritorial application of the securities laws, Rule 10b-5 in particular." So wrote Judge Parker of the Second Circuit Court of Appeals in the opening lines of that court's 2008 decision in Morrison v. National Australia Bank. So vexing was the question to courts that the Supreme Court, after granting certiorari in the Morrison case, decided to preempt it altogether. Setting aside nearly fifty years of federal court jurisprudence, the Supreme Court opinion in Morrison announces a new "transactional test" for courts to use in determining whether the U.S. securities laws apply to a particular claim. ${ }^{2}$

Morrison v. National Australia Bank was the first time the Supreme Court addressed the question of so-called "foreign cubed"3 securities fraud cases, and in fact was the Court's first decision regarding the extraterritorial

${ }^{1}$ Morrison v. Nat'l Austl. Bank, 547 F.3d 167, 168 (2d Cir. 2008).

2 Morrison v. Nat'l Austl. Bank, 130 S. Ct. 2869, 2886 (2010).

3 The term "foreign cubed" is generally credited to Stuart M. Grant and Diane Zilka, who apparently coined the term in their article, The Role of Foreign Investors in Federal Securities Class Actions, in Corporate LAW aNd PRACTICE COURSE HaNDBOOK SERIES NUMBER B-1442 93, 96 (Practising L. Inst. ed., 2004). 
reach of the securities laws. Foreign-cubed cases, brought by foreign plaintiffs against a foreign company in relation to securities purchased abroad, for years have tested the outer limits of the extraterritorial reach of the securities laws, and of the far-reaching prohibition on securities fraud contained in Rule 10b-5. At first blush, these cases are predicated on transactions having little to do with the United States, and it seems hardly surprising that courts would decline to apply U.S. law to them. However, lower courts had previously applied U.S. law to the claims of foreign plaintiffs in a few of these cases, when significant conduct that made up a broader cross-border securities fraud took place in the United States. ${ }^{4}$ Given the increasing integration of world financial markets, and the attendant escalation of transnational securities fraud, such cases have become increasingly common in recent years. ${ }^{5}$

Delineating the extraterritorial reach of Section 10(b) has been a challenge to courts for years. The Supreme Court's attempt to draw a clear boundary has far-reaching consequences for the regulation of transnational securities fraud in today's interconnected global financial markets. While the opinion of the Court at first glance appears to announce a revolutionary new transactional test for application of Section $10(\mathrm{~b}),{ }^{6}$ a closer look at the decision reveals that the Court's opinion is fraught with drafting problems that leave open questions about how the holding will be applied by district courts in future cases. In addition, the Dodd-Frank Act, signed into law just a month after the Supreme Court's opinion in Morrison, contains an amendment to the Securities Exchange Act of 1934 that seems intended to undo the Court's opinion in Morrison, at least as far as actions brought by the Securities and Exchange Commission in transnational securities fraud cases. ${ }^{7}$

${ }^{4}$ See, e.g., In re Vivendi Universal, S.A. Sec. Litig. (Vivendi II), No. 02 Civ. 5571(RJH), 2004 WL 2375830 (S.D.N.Y. Oct. 22, 2004).

${ }^{5}$ See, e.g., Brief of the Securities and Exchange Commission as Amicus Curiae at 4 5, Morrison v. Nat'l Austl. Bank, 547 F.3d 167 (2d Cir. 2008) (No. 07-0583-cv) [hereinafter SEC Brief] (citing cases); PRICEWATERHOUSECOOPERS, 2008 SECURITIES LITIGATION STUDY 43 (Apr. 2009) [hereinafter 2008 STUDY], available at http://10b5.pwc.com/PDF/NY-09-

0894\%20SECURITIES\%20LIT\%20STUDY\%20FINAL.PDF.

${ }^{6}$ See Morrison, 130 S. Ct. at 2886.

7 Dodd-Frank Wall Street Reform and Consumer Protection Act, Pub. L. No. 111203, § 929P(c), 124 Stat. 1376, 1862 (2010) [hereinafter Dodd-Frank Act]. For lawsuits brought by private plaintiffs, the Dodd-Frank Act leaves the Supreme Court opinion in Morrison untouched. See id. However, there is a possibility that Congress will revisit this, because the Dodd-Frank Act also directs the Securities and Exchange Commission to commission a study investigating the wisdom of a further amendment to the Exchange Act that would also apply to claims by private plaintiffs. Id. $\S 929$ Y. 
However, Congress's amendment as drafted may be ineffective, due to a procedural aspect of the Supreme Court's holding in Morrison. ${ }^{8}$ Thus, questions remain in this area of the law. How district courts interpret both the Supreme Court's opinion in the case, as well as the relevant provisions of the Dodd-Frank Act, will have important impacts on a number of major securities fraud cases currently going forward in U.S. courts, including litigation against British Petroleum. A careful analysis of the decision and the relevant policy considerations is therefore warranted, particularly at a time when the global economy remains unsettled and litigation of transnational securities fraud is prevalent in U.S. courts. ${ }^{9}$

Part II of this Article provides a background on extraterritorial application of the securities laws, focusing on the Second Circuit's jurisprudence in the area. Part III turns to the Morrison v. National Australia Bank case, and includes discussion of both the Second Circuit's and the Supreme Court's opinions in the case. Part IV addresses the implications of the Supreme Court's holding in Morrison. Part V discusses the Dodd-Frank Act provisions on extraterritorial application of the securities laws, and also raises the possibility of future Congressional and/or Securities and Exchange Commission action on the issue. Part VI concludes that, though the Supreme Court opinion provides some long-desired certainty about the extraterritorial application of the securities antifraud rules, it does so at the cost of making the private cause of action unavailable in most securities fraud cases with a significant overseas component, potentially harming investor confidence in the globalized financial markets.

\section{EXTRATERRITORIAL APPLICATION OF THE U.S. SECURITIES ANTIFRAUD RULES PRIOR TO MORRISON V. NATIONAL AUSTRALIA BANK}

The majority of transnational securities fraud cases that find their way into U.S. courts are premised on Section 10(b) of the Securities Exchange Act of $1934^{10}$ (the Exchange Act) and its accompanying Rule 10b-5."1 The

\footnotetext{
${ }^{8}$ See infra Part V.A.

${ }^{9}$ In a recent study, securities fraud class actions against foreign issuers represented fourteen percent of total securities class actions filed in the U.S. in 2009, and seventeen percent of the total in 2008. PricewaterhouseCOOPERS, 2009 SECURITIES LITIGATION STUDY 35 (Apr. 2010), available at http://10b5.pwc.com/PDF/NY-100559\%20SEC\%20LIT\%20STUDY_V7\%20PRINT.PDF. In addition, other securities class actions brought in U.S. courts are premised on transnational securities frauds perpetrated by U.S. companies.

1015 U.S.C. $\S 78 \mathrm{j}(\mathrm{b})(2006)$.

1117 C.F.R. $\$ 240.10 \mathrm{~b}-5$ (2010). The securities regulatory regime seeks to prevent and punish fraud via numerous provisions in both the Securities Act of 1933 and the
} 
Supreme Court has characterized Section 10(b) as a "catchall."12 It is a broad stroke rule intended to provide the SEC with a flexible tool "to deal with new manipulative [or cunning] devices." 13 It is also not explicitly restricted to fraud in connection with sales or transactions on U.S. markets, but rather applies to the use of manipulative or deceptive devices or contrivances "in connection with the purchase or sale of any security registered on a national securities exchange or any security not so registered." 14 Courts, in interpreting the language and legislative history of Section 10(b), early on determined that "Congress thus meant $\S 10(\mathrm{~b})$ to protect against fraud in the sale or purchase of securities whether or not these were traded on organized United States markets."'15

In 1942, the SEC used its rule-making authority under Section 10(b) to promulgate Rule 10b-5. In adopting the rule, the Securities and Exchange Commission issued a press release stating: "The new rule closes a loophole in the protections against fraud administered by the Commission by prohibiting individuals or companies from buying securities if they engage in fraud in their purchase." 16 The language of the rule ${ }^{17}$ is unquestionably farreaching, but it is also vague, the details of its application and scope left

Exchange Act. However, the most far-reaching of these provisions is Section 10(b) of the Exchange Act, and its accompanying Rule 10b-5, which are the focus of the case law discussed in this Article.

12 Emst \& Emst v. Hochfelder, 425 U.S. 185, 203 (1976) (citation omitted) (internal quotation marks omitted).

${ }^{13}$ Id. (citation omitted) (internal quotation marks omitted).

1415 U.S.C. § 78j(b) (2006) (emphasis added).

${ }^{15}$ Leasco Data Processing Equip. Corp. v. Maxwell, 468 F.2d 1326, 1336 (2d Cir. 1972).

${ }^{16}$ Rule 10b-5, Exchange Act Release No. 3,230, Fed. Sec. L. Rep. (CCH) (May 21, 1942).

${ }^{17}$ Rule 10b-5 states:

It shall be unlawful for any person, directly or indirectly, by the use of any means or instrumentality of interstate commerce, or of the mails or of any facility of any national securities exchange,

(a) To employ any device, scheme, or artifice to defraud,

(b) To make any untrue statement of a material fact or to omit to state a material fact necessary in order to make the statements made, in the light of the circumstances under which they were made, not misleading, or

(c) To engage in any act, practice, or course of business which operates or would operate as a fraud or deceit upon any person, in connection with the purchase or sale of any security.

17 C.F.R. $§ 240.10 b-5$ (2010). 
almost exclusively to the courts to determine, generating extensive judicial discussion. ${ }^{18}$

Beginning in the 1960s, courts developed two tests for determining the existence of subject matter jurisdiction with respect to the antifraud rules, which became commonly referred to as the "conduct" and "effects" tests. Because of its location at the center of the financial markets, the Second Circuit has been the most influential court in terms of the development of jurisprudence in this area, though other courts have sometimes deviated a bit from the Second Circuit's approach. ${ }^{19}$ First, conduct abroad giving rise to losses in the United States, or harm to the U.S. markets, can give rise to extraterritorial application of the securities laws (the "effects" test). Second, extraterritorial application may exist in certain instances when conduct in the United States causes losses abroad (the "conduct" test). Courts also sometimes applied the two tests together, if possible. ${ }^{20}$

\section{A. The Effects Test}

The effects test focuses on whether U.S. investors or markets were harmed by the alleged fraud. This would typically be the case, for example, where a foreign company's stock trades on a U.S. market. ${ }^{21}$ The effects test was first articulated in 1968 in the seminal case Schoenbaum v. Firstbrook. ${ }^{22}$ In that case, an antifraud action was brought by an American shareholder of a Canadian corporation, Banff Oil Ltd., alleging damages as a result of sales in Canada of the corporation's stock to certain of its controlling shareholders,

18 See Louis Loss \& JoEl SEligman, FUndamentals of SECURITIES REgulation 936 (5th ed. 2003) (noting that "it is difficult to think of another instance in the entire corpus juris in which the interaction of the legislative, administrative rulemaking, and judicial processes has produced so much from so little," and quoting Chief Justice Rehnquist who has called 10b-5 a "judicial oak which has grown from little more than a legislative acorn" (quoting Blue Chip Stamps v. Manor Drug Stores, 421 U.S. 723, 737 (1975))).

${ }^{19}$ See, e.g., Zoelsch v. Arthur Andersen \& Co., 824 F.2d 27, 32 (D.C. Cir. 1987); see also Russell J. Weintraub, The Extraterritorial Application of Antitrust and Securities Laws: An Inquiry into the Utility of a "Choice-of-Law" Approach, 70 TEX. L. REv. 1799, 1812 (1992). Other circuits have developed tests based on the Second Circuit approach, with some variation in the language of the tests. See, e.g., Continental Grain (Austl.) PTY. Ltd. v. Pacific Oilseeds, Inc., 592 F.2d 409, 421 (8th Cir. 1979); SEC v. Kasser, 548 F.2d 109, 116 (3rd Cir. 1977).

20 See, e.g., Itoba Ltd. v. LEP Group PLC, 54 F.3d 118, 122 (2d Cir. 1995).

21 This was so in the first case to articulate the effects test, Schoenbaum $v$. Firstbrook, 405 F.2d 200 (2d Cir. 1968).

22 See id. at 206. 
also foreign, at an unfairly low price. ${ }^{23}$ Though the fraudulent transaction took place entirely abroad, the court found that the usual presumption against extraterritoriality did not apply, at least when the fraudulent transactions involved stock traded on a U.S. exchange. ${ }^{24}$ (Banff Oil's stock traded on the American Stock Exchange as well as the Toronto Stock Exchange.) ${ }^{25}$

The key limitation to the effects test is that courts do not consider foreign conduct with only generalized effects in the United States to be sufficient. ${ }^{26}$ In other words, foreign conduct that affects general confidence in the securities markets would not give rise to a claim under Section 10(b). Rather, courts require a showing of harm to specific interests within the United States, for example, claims by U.S. investors who can assert specific monetary losses as a result of the foreign conduct. ${ }^{27}$

\section{B. The Conduct Test}

The conduct test looks at whether some conduct that was material to the fraud directly caused the harm in question, regardless of the location of the investors or the markets where the stock was sold. ${ }^{28}$ This test, while more soundly rooted in the traditional jurisdictional basis of territoriality than the effects test, ${ }^{29}$ has also proved more difficult to apply than the effects test, and ultimately more controversial. The main difficulty is determining what level of conduct in the U.S. is sufficient to warrant jurisdiction under the Exchange Act. Securities transactions can be made up of many moving parts that often cross territorial boundaries, and fraudulent acts can occur in more than one place. ${ }^{30}$ It is not disputed that under customary international law, concurrent jurisdiction over securities fraud cases is contemplated in some instances. ${ }^{31}$

23 Id. at 204.

24 Id. at 206.

25 Id. at 204.

26 Hannah L. Buxbaum, Multinational Class Actions Under Federal Securities Law: Managing Jurisdictional Conflict, 46 COLUM. J. TRANSNAT'L L. 14, 22 (2007).

27 See id. at 22-23 (citing Interbrew S.A. v. Edperbrascan Corp., 23 F. Supp. 2d 425, 430 (S.D.N.Y. 1998)).

${ }^{28}$ Bersch v. Drexel Firestone, 519 F.2d 974, 993 (2d Cir. 1975) (asserting that U.S. securities laws apply to losses from sales of securities to foreigners outside the United States only when acts or culpable failures to act within the United States directly caused such losses).

29 See RESTATEMENT (THIRD) OF FOREIGN RELATIONS LAW § 402(1)(a) (1987).

30 See Stephen J. Choi \& Andrew T. Guzman, The Dangerous Extraterritoriality of American Securities Law, 17 Nw. J. INT'L L. \& BUS. 207, 216-17 (1996).

31 P.M. Roth, Reasonable Extraterritoriality: Correcting the "Balance of Interests", 41 INT'L \& COMP. L.Q. 245, 253 (1992). 
The problem is that this can sometimes lead to instances of jurisdictional conflict, where the applicable policies and rules of the interested countries are in conflict, and to possible overregulation. Too broad an extraterritorial application of the securities antifraud rules may amount to an impermissible interference with foreign securities markets. ${ }^{32}$

The Second Circuit addressed this question in Bersch v. Drexel Firestone, Inc., ${ }^{33}$ asserting that the U.S. securities laws only apply to losses from sales of securities to foreigners outside the United States when acts or culpable failures to act directly caused such losses. ${ }^{34}$ Lesser thresholds of conduct would be necessary when conduct causes losses in the United States (no U.S. conduct is necessary), or to Americans residing abroad. (Acts or omissions in the United States must have "significantly contributed" to such losses.) $)^{35}$ The Bersch standard relating to conduct causing losses to foreigners has been further refined over time to hold that subject matter jurisdiction exists over securities claims if "activities in [the United States] were more than merely preparatory to a fraud and culpable acts or omissions occurring here directly caused losses to investors abroad." 36 Of course, this left a number of open questions, including what acts will be considered "merely preparatory" and what constitutes "directly caused"; lower courts continued to struggle with these questions, and the Second Circuit provided little guidance. Until the Supreme Court decision in Morrison, the Supreme Court had never addressed the issue.

\section{Application of Section 10(b) in Foreign-Cubed Cases}

In recent years, district courts have increasingly been faced with cases implicating the extraterritorial application of the antifraud provisions of the U.S. securities laws, and of Section 10(b) in particular. ${ }^{37}$ This is not surprising in light of the globalization of the world's financial markets, and the increasing incidence of cross-listing, dual-listing, and other cross-border capital raising efforts. With the increasing incidence of transnational

32 See Morrison v. Nat'l Austl. Bank, 130 S. Ct. 2869, 2884 (2010) ("We know of no one who thought that the Act was intended to 'regulat[e]' foreign securities exchanges-or indeed who even believed that under established principles of international law Congress had the power to do so.").

33 519 F.2d 974 (2d Cir. 1975).

34 Id. at 993.

$35 \mathrm{Id}$.

36 Morrison v. Nat'l Austl. Bank, 547 F.3d 167, 171 (2d Cir. 2008).

37 Buxbaum, supra note 26, at 16-17. 
securities fraud, investors have become more proactive in seeking redress. ${ }^{38}$ Often this leads them to the United States, with its well-developed class action mechanism in securities fraud cases. ${ }^{39} \mathrm{~A}$ particular challenge has been presented to the courts in the form of the increasing incidence of foreign-cubed cases. ${ }^{40}$ Such cases test the outer limits of the extraterritorial application of the U.S. antifraud rules on the basis of the conduct test, ${ }^{41}$ and also highlight the problems with the conduct test.

A number of recent district court decisions have applied Section 10(b) to the claims of foreign-cubed plaintiffs. For example, In re Gaming Lottery Securities Litigation ${ }^{42}$ involved claims by both U.S. and foreign plaintiffs against a Canadian corporation for fraud in connection with the sale of securities on both American and Canadian exchanges. ${ }^{43}$ The relevant U.S. conduct included the acquisition of a Washington corporation, which the defendant company proceeded to operate without receiving regulatory approval from Washington state gaming regulators for operations. ${ }^{44}$ In addition, the company reported increases in earnings and stockholder equity based on the acquired entity's financials, even though they knew they would not be able to obtain regulatory approval for the entity's operations, therefore making the statements regarding the U.S. subsidiary's earnings misleading. ${ }^{45}$ There, the court certified both Canadians and U.S. investors as lead plaintiffs, ${ }^{46}$ finding that sufficient conduct had occurred in the United States that was "more than merely preparatory" to the alleged fraud so as to confer subject matter jurisdiction over the Canadians' claims as well as the domestic plaintiffs' claims. ${ }^{47}$

$38 \mathrm{Id}$.

${ }^{39}$ See 2008 STUDY, supra note 5 , at 43 (noting that securities class actions against foreign issuers hit an all-time high in 2008).

40 Buxbaum, supra note 26, at 17.

41 To date, no courts have applied the antifraud rules in a foreign-cubed case on the basis of the effects test. Stephen J. Choi \& Linda J. Silberman, Transnational Litigation and Global Securities Class Actions, 2009 WIS. L. REV. 465, 476 (2009).

4258 F. Supp. 2d 62 (S.D.N.Y. 1999).

43 Id. at $64-65$.

44 Id. at $65-67$.

$45 \mathrm{Id}$.

46 The process of appointing a lead plaintiff in multinational securities class actions often invokes the question of the extraterritorial application of the U.S. antifraud rules. See Buxbaum, supra note 26, at 27-29.

47 In re Gaming Lottery, 58 F. Supp. 2d at 73-74. 
Similarly, in In re Vivendi Universal, S.A. Securities Litigation (Vivendi II), ${ }^{48}$ the issuing company's CEO and CFO moved to New York in order to oversee a number of acquisitions of U.S. companies, and it was debt taken on in connection with these acquisitions that was the focus of the allegedly false and misleading statements at issue in the lawsuit. ${ }^{49}$ The U.S.-based conduct was therefore the basis for the false statements, and was found to be "integral and not merely preparatory to the alleged fraud upon foreign purchasers of Vivendi shares on foreign exchanges." 50

In a third case brought around the same time as Vivendi, In re National Australia Bank Securities Litigation, the district court declined to apply Section 10(b) to the claims of the foreign plaintiffs in the case. ${ }^{51}$ However, it was a "close call," 52 and the plaintiffs appealed to the Second Circuit Court of Appeals, ${ }^{53}$ which until then had never ruled on a foreign-cubed case. Because of the uncertainty among district courts about how to apply the conduct test to these cases, resulting in fragmentation and unpredictable results ${ }^{54}$ the Second Circuit opinion was widely anticipated. It also marked the next step in a long odyssey for the parties in the case that would lead all the way to the Supreme Court.

\section{A Procedural Note}

Until the Supreme Court decision in Morrison v. National Australia Bank, federal courts had always treated the question of extraterritorial application of the securities antifraud provisions as a question of subject

48 No. 02 Civ. 5571(RJH), 2004 WL 2375830 (S.D.N.Y. Oct. 22, 2004). The Vivendi litigation was ongoing at the time of the Supreme Court's decision in Morrison. A jury verdict was issued on January 29, 2010, finding the company liable to investors. Court Finds Vivendi Liable for Misleading Investors, N.Y. TIMES, Jan. 30, 2010, at B3 [hereinafter Vivendi Liable], available at $\mathrm{http}: / /$ www.nytimes.com/2010/01/30/business/30vivendi.html? $\mathrm{r}=1$. However, following the Supreme Court's decision in Morrison, a district court dismissed the claims of all purchasers of Vivendi ordinary shares, and limited the case to claims of only certain purchasers of Vivendi's American Depositary Receipts. In re Vivendi Universal, S.A. Sec. Litig. (Vivendi III), No. 02 Civ. 05571(RJH)(HBJ), 2011 WL 590915, at *8, *12 (S.D.N.Y. Feb. 17, 2011); see also infra Part IV.C.

49 Vivendi II, 2004 WL 2375830, at *1.

50 Id. at $* 4$ (citation omitted).

51 In re Nat'l Austl. Bank Sec. Litig., No. 03 Civ. 6537(BSJ), 2006 WL 3844465, at $*_{1}$, *8 (S.D.N.Y. Oct. 25, 2006).

52 Id. at $* 8$.

53 See Morrison v. Nat'l Austl. Bank, 547 F.3d 167, 171-72 (2d Cir. 2008).

${ }^{54}$ See Buxbaum, supra note 26, at 24. 
matter jurisdiction. ${ }^{55}$ However, this is somewhat of a misnomer as the real question is one of jurisdiction to prescribe, ${ }^{56}$ or rather, whether or not the allegedly fraudulent acts fall within the ambit of the securities antifraud rules. The Supreme Court in Morrison corrected this "threshold error" in the Second Circuit's longstanding approach to questions of the extraterritorial reach of Section $10(\mathrm{~b}) .57$ The Supreme Court affirmed that the question was one of merits, rather than an issue of subject matter jurisdiction, which only "refers to a tribunal's power to hear a case."58 Jurisdiction over lawsuits alleging violations of Section $10(\mathrm{~b})$ and Rule 10b-5 is conferred by Section 27 of the Exchange Act. ${ }^{59}$ The location of fraudulent conduct therefore does not affect this conferral of jurisdiction. ${ }^{60}$ It is only relevant as to whether or not a particular fraudulent scheme or act violates Section $10(\mathrm{~b}) .61$ The Court acknowledged this, but did not find it necessary to remand in light of this error, because "a remand would only require a new Rule 12(b)(6) label for the same Rule 12(b)(1) conclusion."62 The Supreme Court's opinion in Morrison thus addressed whether the petitioners' allegations stated a claim for relief under Section 10(b). ${ }^{63}$

\section{MORRISON V. NATIONAL AUSTRALIA BANK}

\section{A. Morrison v. National Australia Bank in the Lower Courts}

Morrison v. National Australia Bank underscored the particular difficulties raised by foreign-cubed cases, and reignited debate on the proper scope of the extraterritorial application of the U.S. securities laws on the basis of conduct. The impetus for the case was a series of write-downs made by National Australia Bank (NAB) in 2001, due to the allegedly fraudulent

55 See Bersch v. Drexel Firestone, Inc., 519 F.2d 974, 984-90 (2d Cir. 1975).

56 RESTATEMENT (THIRD) OF FOREIGN RELATIONS LAW $\$ 401$ (defining jurisdiction to prescribe as the power of a country to "make its law applicable to the activities, relations, or status of persons, or the interests of persons in things"); see also ANDREAS F. LOWENFELD, INTERNATIONAL LITIGATION \& ARBITRATION 55 n.1, 102-03 (3d ed. 2006).

57 Morrison v. Nat'l Austl. Bank, 130 S. Ct. 2869, 2876-77 (2010).

${ }^{58} \mathrm{Id}$. at 2877 (citations omitted) (internal quotation marks omitted).

5915 U.S.C. $\S 78$ aa (2006).

60 See id.

${ }^{61} \mathrm{Id}$.

62 Morrison, 130 S. Ct. at 2877.

${ }^{63}$ Id. This correction was not unexpected, as the Court had recently criticized courts' "less than meticulous" treatment of the distinction between an element of a claim for relief and a limitation on subject matter jurisdiction. See Arbaugh v. Y \& H Corp., 546 U.S. 500, 511 (2006). 
overvaluation of one of NAB's American subsidiaries, a mortgage servicing company based in Florida called HomeSide, Inc. The write-downs totaled approximately $\mathrm{A} \$ 4$ billion, ${ }^{64}$ and constituted the largest single loss reported in Australian corporate history up to that point. ${ }^{65}$ The bank's shares, trading on the Australian Stock Exchange, as well as on exchanges in Tokyo, New Zealand, London, and in the form of American Depositary Receipts on the New York Stock Exchange, initially dropped between ten and thirteen percent following the write-downs. 66

In response to these losses, a group of international shareholders of the bank brought suit against NAB in U.S. federal court, claiming violations of the securities antifraud rules, including Rule $10 \mathrm{~b}-5$. The plaintiffs alleged that the overvaluation of HomeSide was the result of intentional misuse of valuation models by certain of its employees and executives who "had been cooking HomeSide's books since at least April 1999," in violation of the U.S. securities laws. ${ }^{67}$ These misstatements of HomeSide's value were sent to NAB headquarters in Australia and incorporated into NAB's own financial statements, then disseminated to the public in regulatory filings and press releases, including filings with the SEC made in connection with NAB's American Depositary Receipts (ADRs). ${ }^{68}$

Though calling the case a "close call,"69 the district court dismissed the case, stating that "the transactions of which [the] plaintiffs complain [are] fundamentally foreign in nature, and thus beyond the scope of this Court's jurisdiction under the Exchange Act."70 On appeal, the Second Circuit

64 "A\$" denotes Australian dollars. According to statistics of the Reserve Bank of Australia, the Australian dollar was worth approximately 0.53 U.S. dollars on September 3, 2001, the date of NAB's announcement of its second HomeSide-related write-down. See Exchange Rate Data, RESERVE BANK OF AUSTL., http://www.rba.gov.au/statistics/hist-exchange-rates/1999-2002.xls (last visited Jan. 27, 2011).

65 Shann Turnbull, Men Behaving Badly in Banking: Revealing the Irrelevance of Best Practices in Corporate Governance, in ANTHONY TARANTINO, GOVERNANCE, RISK and Complance Handbook: Technology, Finance, Environmental, and INTERNATIONAL GUIDANCE AND BEST PRACTICES 82, 87 (2008), available at http://media.wiley.com/product_ancillary/9X/04700958/DOWNLOAD/chapter73.pdf (article appears at pages 82 through 95 of "URL Contents"-article title appears in book but text is only available online).

${ }^{66}$ Brief and Special Appendix for Plaintiffs-Appellants at 16, Morrison v. Nat'l Austl. Bank, 547 F.3d 167 (2d Cir. 2008) (No. 07-0583-cv).

67 Id. at 21.

68 See id. at 36-37.

69 In re Nat'l Austl. Bank Sec. Litig., No. 03 Civ. 6537(BSJ), 2006 WL 3844465, at *8 (S.D.N.Y. Oct. 25, 2006).

${ }^{70} \mathrm{Id}$. at $* 2$. 
affirmed the district court's outcome. ${ }^{71}$ However, the Second Circuit left open the possibility that, on other facts, it would hear a foreign-cubed claim by foreign plaintiffs. ${ }^{72}$ Defendants had argued for a bright-line rule barring foreign-cubed claims brought solely on the basis of conduct in the United States, if there were no allegation of harm to domestic investors or markets. ${ }^{73}$ The Second Circuit refused to adopt such a rule, because it could not anticipate "all the circumstances in which the ingenuity of those inclined to violate the securities laws should result in their being subject to American jurisdiction." "74 Instead, the court determined that the conduct and effects tests were the proper lens through which to examine the question of extraterritoriality. ${ }^{75}$ It went on to say that the issue before it in Morrison "boils down to what conduct comprises the heart of the alleged fraud." $76 \mathrm{On}$ the facts of the case, though, the Second Circuit found that acts or omissions in Australia were "more directly responsible" for the plaintiffs' injuries, and declined to exercise jurisdiction over the case. ${ }^{77}$

Comparing the facts of Morrison v. National Australia Bank to the facts of cases such as In re Gaming Lottery and Vivendi, it seems clear that Morrison could easily have come out the other way; ${ }^{78}$ indeed, the judge in In re Gaming Lottery might well have found for the plaintiffs in Morrison. Though the Second Circuit claimed to be applying its "usual rules,"79 the court struggled with the issue of whether conduct in the U.S. had "directly caused" the harm abroad, and used novel language to find that acts or omissions in Australia were "more directly responsible" for the plaintiffs' injuries. ${ }^{80}$ This "more directly" language had never appeared in any prior case, making it seem like the court was straining to avoid exercising jurisdiction in this case. Certainly, the court's decision to decline to hear the case was perfectly reasonable in light of the significantly Australian aspects of the case. At the same time, it would not have been "wrong" under the conduct test to find that the plaintiffs had articulated a claim for relief under Section 10(b) and Rule 10b-5.

${ }^{71}$ Morrison v. Nat'l Austl. Bank, 547 F.3d 167, 177 (2d Cir. 2008).

$72 \mathrm{Id}$. at 175.

${ }^{73} \mathrm{Id}$. at 174 .

${ }^{74} \mathrm{Id}$. at 175 .

${ }^{75} \mathrm{Id}$.

${ }^{76} \mathrm{Id}$.

77 Morrison, 547 F.3d at 176.

78 See Choi \& Silberman, supra note 41, at 492 ("Another court, analyzing the same facts, might have decided the case differently ....").

79 Morrison, 547 F.3d at 172.

$80 \mathrm{Id}$. at 176 (emphasis added). 


\section{B. The Supreme Court Opinion}

Plaintiffs in Morrison shortly appealed to the Supreme Court, and the Court granted certiorari on November 30, 2009.81 Because it would be the first time the Supreme Court would address the issue of the extraterritorial reach of the securities antifraud rules, the opinion was widely anticipated. Issued on June 24, 2010, the Supreme Court's opinion in the case was unanimous as to the judgment, which affirmed the Second Circuit's ruling. ${ }^{82}$ However, the majority's opinion went beyond a simple affirmation, overruling nearly fifty years of federal court jurisprudence based on the Second Circuit's conduct and effects tests and articulating a new test for determining the extraterritorial reach of Section 10(b) of the Exchange Act.

From as early as March 2010, when the Supreme Court heard oral arguments in the case, the probable outcome was clear. In early questioning of the petitioners' attorney, Justice Ginsburg observed, "I mean, this case is Australian plaintiff, Australian defendant, shares purchased in Australia. It has 'Australia' written all over it." 83 When the Supreme Court's opinion was issued a few months later, Justice Scalia, writing for the Court, declared that "Section 10(b) reaches the use of a manipulative or deceptive device or contrivance only in connection with the purchase or sale of a security listed on an American stock exchange, and the purchase or sale of any other security in the United States." 84 Since all the aspects of the purchase complained of by the plaintiffs in the case occurred outside the United States, the Court affirmed dismissal of the complaint. ${ }^{85}$

The Court's decision to set aside the conduct and effects tests relied primarily on a textual argument. However, there was also a policy rationale for the decision, which, though not heavily developed by the Court, was

81 Morrison v. Nat'l Austl. Bank, 130 S. Ct. 783, 783 (2009).

82 Morrison v. Nat'l Austl. Bank, 130 S. Ct. 2869, 2888 (2010). Justice Sotomayor took no part in the consideration of the case, see id., as she had sat on the Second Circuit when that court heard the case. However, it can be assumed that she would have at least concurred in the judgment, given how the Second Circuit decided the case. Justice Breyer wrote a brief and narrow concurrence. See id. (Breyer, J., concurring). He stated that the purchased securities at issue in Morrison were not registered with the SEC, and the purchases "took place entirely in Australia and involved only Australian investors." Id. In light of the presumption against extraterritoriality, he did not believe that Section $10(b)(1)$ or (2) therefore reached plaintiffs' claims. Id. Justice Stevens, joined by Justice Ginsburg, wrote a more lengthy concurrence arguing for preservation of the Second Circuit test. See id. at 2888-95 (Stevens, J., concurring).

83 Transcript of Oral Argument at 7, Morrison, 130 S. Ct. 2869 (No. 08-1191).

84 Morrison, 130 S. Ct. at 2888.

$85 \mathrm{Id}$. 
extensively treated by commentators prior to the Court's decision in Morrison. ${ }^{86}$ Predictably, Justice Scalia's discussion of the law began with a reference to the presumption against extraterritoriality ${ }^{87}$ that the Supreme Court first articulated in the American Banana case. ${ }^{88}$ This principle, as restated by Justice Scalia, is a canon of construction that directs courts to assume that Congress did not intend a law to have extraterritorial effect unless such intent is clearly expressed in the statute ${ }^{89}$ On the basis of this principle, Justice Scalia proceeded to sharply criticize over forty years of Second Circuit and other federal court jurisprudence, which he viewed as disregarding the presumption against extraterritoriality. ${ }^{90}$ After describing the conduct and effects tests, he observed, "The Second Circuit never put forward a textual or even extratextual basis for these tests."

Justice Scalia then asserted a number of arguments based on the text of the Exchange Act in support of the Court's decision to set aside the Second Circuit's tests. To begin, the Court asserted that it would apply the presumption against extraterritoriality in all cases, "[r]ather than guess anew" at what Congress would have wanted had it thought about the situation before. ${ }^{92}$ Applying the presumption against extraterritoriality to Section 10(b) of the Exchange Act, the Court addressed three arguments made by petitioners in the case, as well as by the Solicitor General writing for the United States as Amicus Curiae, that the presumption against extraterritoriality should be overcome. First, Section 10(b) refers to interstate commerce, which includes "trade, commerce, transportation, or communication ... between any foreign country and any State ...."93 However, relying on past precedent, the Court asserted that this general reference to foreign commerce, without more, does not defeat the presumption against extraterritoriality. ${ }^{94}$

86 See, e.g., Choi \& Guzman, supra note 30, at 219-39; Choi \& Silberman, supra note 41 , at $480-88$.

87 See Morrison, 130 S. Ct. at 2877.

88 Am. Banana Co. v. United Fruit Co., 213 U.S. 347, 357-59 (1909).

89 Morrison, 130 S. Ct. at 2877 (citing EEOC v. Arabian Am. Oil Co., 499 U.S. 244, 248 (1991)).

90 Id. at 2878-79 ("With Schoenbaum and Leasco on the books, the Second Circuit had excised the presumption against extraterritoriality from the jurisprudence of $\S 10(\mathrm{~b}) \ldots . .$.$) .$

91 Id. at 2879.

92 Id. at 2881.

93 15 U.S.C. $\S 78 \mathrm{c}(\mathrm{a})(17)$ (2006).

${ }^{94}$ Morrison, 130 S. Ct. at 2882 (citing Arabian Am. Oil Co., 499 U.S. at 251). 
The second textual argument made by the petitioners and rebutted by the Court was a reference to Congress's description of the purposes of the Exchange Act, which included the observation that " prices established and offered in [securities] transactions are generally disseminated and quoted throughout the United States and foreign countries." "95 Again, though, the Court found this unpersuasive: "The antecedent of 'such transactions' . . . is found in the first sentence of the section, which declares that 'transactions in securities as commonly conducted upon securities exchanges and over-thecounter markets are affected with a national public interest."'96 Justice Scalia was dismissive of the idea that such "national public interest" could pertain to "transactions conducted upon foreign exchanges and markets." 97

Petitioners' final textual argument, intended to support their contention that Section 10(b) applies extraterritorially, relied on Section 30(b) of the Exchange Act. This section provides: "The provisions of this chapter or of any rule or regulation thereunder shall not apply to any person insofar as he transacts a business in securities without the jurisdiction of the United States," unless he does so in violation of regulations promulgated by the Commission "to prevent the evasion of this chapter." 98 The Solicitor General argued that if the Exchange Act did not apply extraterritorially, this provision would have no relevance. 99 The Court disagreed, stating that "it would be odd for Congress to indicate the extraterritorial application of the whole Exchange Act by means of a provision imposing a condition precedent to its application abroad." 100 Instead, the Court believed the provision was "directed at actions abroad that might conceal a domestic violation, or might cause what would otherwise be a domestic violation to escape on a technicality."101 While the Court did not find the Section 30(b) argument persuasive enough to override the presumption against extraterritoriality, ${ }_{102}$ this observation does perhaps encourage the Commission to promulgate regulations under Section 30 that were heretofore perceived as unnecessary because of the broad reach of Section 10(b) and Rule 10b-5.103

95 Brief for Petitioners at 39, Morrison, 130 S. Ct. 2869 (No. 08-1191) (quoting 15 U.S.C. $\S 78 b(2)(2006))$.

96 Morrison, 130 S. Ct. at 2882 (quoting 15 U.S.C. $\S 78 \mathrm{~b}(2006)$ ).

97 Id.

9815 U.S.C. $\$ 78 \mathrm{dd}(\mathrm{b})(2006)$.

99 Brief for the United States as Amicus Curiae Supporting Respondents at 14, Morrison, 130 S. Ct. 2869 (No. 08-1191).

100 Morrison, $130 \mathrm{~S}$. Ct. at 2882.

101 Id at $2882-83$.

102 Id.

103 See infra Part V.B. 
Finally, the Supreme Court addressed petitioners' argument that the Morrison case did not require extraterritorial application because of the significant domestic conduct that had occurred. Here the Court moved away from its purely textual and precedent-based argument to adopt the new transaction-based rule it articulated for when Section 10(b) and Rule 10b-5 could apply. While acknowledging that "it is a rare case of prohibited extraterritorial application that lacks all contact with the territory of the United States," the Court asserted that "the focus of the Exchange Act is not upon the place where the deception originated, but upon purchases and sales of securities in the United States."104 In justifying this assertion, the Court pointed to the "in connection with" clause of Section 10(b), stating that the "purchase-and-sale transactions" referred to there "are the objects of the statute's solicitude."105 Because the purchase-and-sale transactions in Morrison occurred outside the United States, and the case involved "no securities listed on a domestic exchange," the petitioners had failed to state a claim upon which relief could be granted. ${ }^{106}$

\section{IMPLICATIONS OF THE SUPREME COURT DECISION FOR REGULATION of TRANSNATIONAL SECURITIES FRAUD}

Though the Supreme Court's decision was primarily based on the text of the statute, the Court hinted at a number of important policy issues underlying the holding, examination of which will illuminate the significant impact this decision could have on regulation of the securities markets. First, as the Supreme Court opinion pointed out in a harsh criticism of the Second Circuit's traditional tests, the tests have proven incredibly difficult to administer. ${ }^{107}$ Commentators have been making this same criticism of the tests for years. ${ }^{108}$ This has led to uncertainty for the relevant actors as courts have applied the tests on a case-by-case basis, sometimes resulting in divergent outcomes in cases with substantially similar factual scenarios. 109 Such uncertainty may be particularly costly in an area of the law that bears directly upon economic and business interests. Second, the extraterritorial application of the securities laws has sometimes led to jurisdictional conflicts with other countries that also seek to apply their regulations to a particular

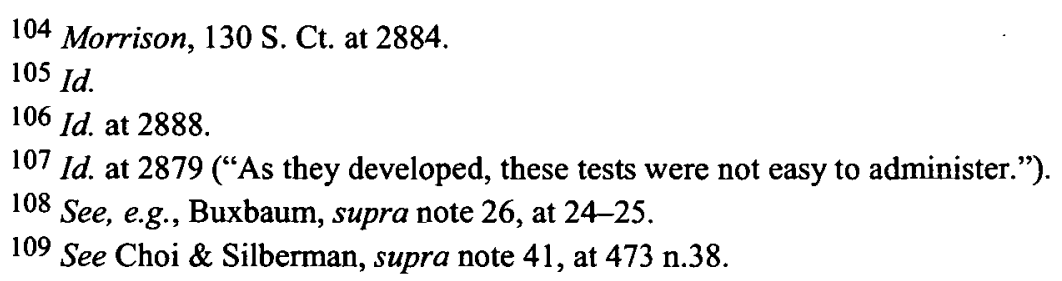


transaction. ${ }^{110}$ Third, the decision could have a very real impact on investors, raising questions about the proper level of regulatory intensity, ${ }^{111}$ the advisability or necessity of private rights of action for antifraud enforcement, and how to strike a balance between under- and over-regulation of securities transactions in a globalized world. The Supreme Court's opinion expresses an underlying skepticism about the value of the private right of action in deterring and punishing securities fraud, but also evinces a disregard for the interconnectedness of the world financial markets. In addition, the Court's new transactional test carries particular implications for specific groups of actors who engage in cross-border securities transactions. This section of the Article will address each of these issues in turn.

\section{A. Uncertainty, Jurisdictional Conflict, and International Cooperation}

First, it is unquestionable that the Second Circuit's approach created uncertainty for issuers regarding potential liability under the U.S. antifraud rules. ${ }^{112}$ Many felt this had a chilling effect on valuable economic activity in the United States, as foreign companies would limit their business within the United States in order to avoid the risk of having to defend against costly litigation in U.S. courts. ${ }^{113}$ For example, if the Morrison case had come out the other way, this could potentially have discouraged foreign companies from investing in U.S. subsidiaries. Furthermore, as multiple countries can often claim a legitimate regulatory interest in regulating the same conduct, the cost of multiple regulations becomes burdensome to business. In some cases, concurrent jurisdiction is not a problem, but when multiple countries are able to assert their regulatory jurisdiction over conduct because of effects on their citizens, and one or more other countries are also able to apply their laws and regulations because of conduct within their borders, the cost of compliance with all these rules can become prohibitive. It is also becoming increasingly costly for regulators and judicial systems to enforce the law, as more and more transactions can implicate a country's regulatory system on

${ }^{110} I d$. at $60-64$.

111 See generally Howell E. Jackson, Variation in the Intensity of Financial Regulation: Preliminary Evidence and Potential Implications, 24 YALE J. ON REG. 253 (2007).

112 See Buxbaum, supra note 26, at 67.

113 See generally COMM. ON CAPITAL MKTS. REgULATION, INTERIM REPORT OF THE COMM. ON CAPITAL MKTS. REgULATION (2006), available at http://capmktsreg.org/pdfs/11.30Committee_Interim_ReportREV2.pdf (discussing the burden of uncertainty in Rule 10b-5 litigation on issuers). 
the basis of tenuous contacts with that country, which may undermine the overall effectiveness of regulation. ${ }^{114}$

Besides the negative impact that this uncertainty and overlapping regulation had on businesses, it also led to diplomatic controversies, as foreign governments saw their interests impinged upon. ${ }^{115} \mathrm{~A}$ number of important constituencies submitted amicus briefs to the Supreme Court supporting their view that extraterritorial application of the U.S. securities laws under the old conduct and effects tests constituted regulatory overreaching. Australia, the United Kingdom, and France all submitted amicus briefs to the Supreme Court, urging affirmance of the Second Circuit's decision in the case, and also advocating a limit on the application of Section $10(\mathrm{~b})$ to foreign-cubed cases. ${ }^{116}$ The United Kingdom, for example, urged in its amicus brief:

Although there is no U.K. party in this case, the broad assertion of extraterritorial jurisdiction by United States courts implicates the legitimate sovereign interests and policy choices of the United Kingdom. The risk of infringing upon the sovereignty of other nations is a particular concern with respect to the regulation of securities transactions, especially in cases involving foreign purchasers, a foreign issuer, and alleged harm suffered in transactions on a foreign securities exchange (so-called "foreign-cubed" securities cases). ${ }^{117}$

Echoes of these same concerns have long been asserted by courts and commentators in favor of a limited extraterritorial application of the securities laws. ${ }^{118}$ Too broad an extraterritorial application of the U.S. antifraud rules can result in jurisdictional conflict with other countries seeking to regulate the same transaction. Each country with a developed market for securities has made legislative choices regarding how to regulate securities fraud. For example, the laws in many countries do not (or did not

114 This is particularly poignant in the United States in the context of the foreigncubed cases, where tenuous links to the United States lead to often-costly litigation in U.S. courts.

115 See, e.g., Brief of the Government of the Commonwealth of Australia as Amicus Curiae in Support of the Defendants-Appellees at 2, Morrison v. Nat'l Austl. Bank, 130 S. Ct. 2869 (2010) (No. 08-1191).

116 See id. at 28, 38; Brief for the Republic of France as Amicus Curiae in Support of Respondents at 4-5, 34, Morrison, 130 S. Ct. 2869 (No. 08-1191); Brief of the United Kingdom of Great Britain and Northern Ireland as Amicus Curiae in Support of Respondents at 2, 29, Morrison, 130 S. Ct. 2869 (No. 08-1191) [hereinafter U.K. Brief].

117 U.K. Brief, supra note 116, at 2.

118 See, e.g., Buxbaum, supra note 26, at 60-64. 
until very recently) permit class actions in the securities law context. ${ }^{119}$ Broad extraterritorial application of the U.S. antifraud rules can interfere with these legislative choices. ${ }^{120}$ In addition, when multiple countries seek to regulate the same conduct, this can create a situation where investors will forum-shop to find the most favorable forum in which to bring their suit. In that case, countries that have made the regulatory judgment not to allow private enforcement of their antifraud rules, for example, could therefore have their legislative judgment thwarted. ${ }^{121}$

While the foregoing arguments clearly support the Supreme Court's decision, some U.K.-based commentators have characterized the Supreme Court's decision in Morrison as a "major step back for UK investors" and other investors around the world. ${ }^{122}$ While the U.K. government in its amicus brief argued that U.K. institutions could readily bring securities fraud claims in the U.K., ${ }^{123}$ that may not be "an accurate picture."124 Of course, just because the United States legal system may be more shareholder-friendly in its substance and in the procedural mechanism for shareholder class action suits, this does not mean that the U.S. courts should be able to police the world for securities fraud. ${ }^{125}$ However, recent shareholder activism in other countries has shed light on the fact that other systems may require reform to effectively regulate securities fraud, and there is an argument to be made that some shareholder activism in other countries, such as the U.K., may have been "developing on the back of claims in the US." 126 Therefore, in the interest of ensuring the integrity of the world's financial markets and effective regulation of securities fraud, the Second Circuit's traditional tests

119 See id. at 61 .

120 U.K. Brief, supra note 116, at 15-16; see also Morrison, 130 S. Ct. at 2885-86.

121 Joshua G. Urquhart, Comment, Transnational Securities Fraud Regulation: Problems and Solutions, 1 CHI. J. INT'L L. 471, 474 (2000).

122 David Greene, The US Ruling on Morrison $v$ NAB Deals a Blow to the International Claims Culture, THE GUARDIAN (June 28, 2010), http://www.guardian.co.uk/law/2010/jun/28/supreme-court-morrison-national-australiabank.

123 See U.K. Brief, supra note 116, at 8-10.

124 Greene, supra note 122.

125 Nor is it settled that the U.S.-style class action is the best method of policing securities fraud. This is an important debate, but elaboration of it is beyond the scope of this Article. The issue has been treated carefully elsewhere. See, e.g., John C. Coffee, Jr., Reforming the Securities Class Action: An Essay on Deterrence and Its Implementation, 106 Colum. L. REV. 1534 (2006); Amanda M. Rose, Reforming Securities Litigation Reform: Restructuring the Relationship Between Public and Private Enforcement of Rule 10b-5, 108 COLUM. L. REV. 1301 (2008).

126 Greene, supra note 122. 
may have served an important role in preventing much fraud from slipping through the cracks in the global financial regulatory system.

The Supreme Court's decision thus may be a setback for foreign shareholders, at a time when shareholder confidence is already on shaky ground in the wake of the 2008 financial crisis. At the same time, it could be the galvanizing agent for a push to reform other countries' systems to become more shareholder-friendly. With more limited access to U.S. class actions, investors and other shareholders' interest groups in other countries may put increased pressure on their own governments to improve their domestic antifraud regulation. In fact, even before the Court's decision in Morrison, the benefits of the class action mechanism were beginning to be recognized in other countries. A number of countries have recently adopted a form of collective-action lawsuit, or otherwise modified their laws to ease the way for private enforcement of securities fraud claims, including Australia, parts of Europe, and China. ${ }^{127}$

Another possible side effect of the Supreme Court's decision could be its impact on the potential for a multilateral negotiated solution. ${ }^{128}$ As noted in a recent report by the International Bar Association (IBA), "There is a profound consensus among regulators, academics, financial institutions and others that the regulatory framework of the international financial markets needs to undergo a fundamental change to address the diminished influence of national and regional securities regulators over cross-border financial activities." 129 This consensus applies to all areas of financial regulation. ${ }^{130}$

127 See, e.g., Xi Chao, Private Enforcement of Securities Law in China: Daqing Lianyi Co v ZHONG Weida and Others (2004) Heilongjiang High Court, 1 J. COMP. L. 492, 493 (2006); Olivier Cavézian et al., Class Actions in Europe: Reality or Myth? The Example of France, JONES DAY 9-12 (Oct. 2009), http://www.jonesday.com/files/Publication/ff7fd833-8640-443c-bb46d6e756864345/Presentation/PublicationAttachment/6e60f00f-0d2a-4c0c-b986d7982522c1f6/Class\%20Actions\%202009.pdf; Jonathan Redwood, Limitations of U.S. Securities Litigation Against Australian Companies by Australian Plaintiffs, LIST A BARRISTERS 1 , 5-6 (Dec. http://www.barristers.com.au/www/392/1001127/displayarticle/recent-publications-1001461.html.

128 There is some consensus among scholars that international cooperation would be the optimal approach to the problem. See, e.g., Buxbaum, supra note 26, at 68; Andrew T. Guzman, Choice of Law: New Foundations, 90 GEO. L.J. 883, 935 (2002). However, there is little if any agreement as to the form that a multilateral solution should take. I have treated this subject more fully elsewhere. See Genevieve Beyea, Transnational Securities Fraud and the Extraterritorial Application of U.S. Securities Laws: Challenges and Opportunities, 1 GLOBAL BUS. L. REV. (forthcoming Apr. 2011).

${ }^{129}$ INT'L BAR ASS'N, REPORT OF THE TASK FORCE ON EXTRATERRITORIAL JURISDICTION 273 (2009), http://tinyurl.com/taskforce-etj-pdf. 
However, it is particularly prescient in the context of deterring and punishing securities fraud, which is necessary to maintain stability and prosperity in the capital markets. Transnational securities fraud provides an ideal backdrop for international cooperation. First of all, the problems caused by securities fraud-lack of investor confidence, reduced liquidity in the markets, and depressed prices - are no longer contained to one country or region but will affect capital markets throughout the world. ${ }^{131}$ Furthermore, most countries with securities markets have regulations aimed at discouraging financial fraud. ${ }^{132}$ While the prohibitions on fraud vary in form, in substance they all aim to eradicate essentially the same behavior. ${ }^{133}$ Similarly, all countries with active securities markets have an interest in reducing the inefficiencies created by overregulation and jurisdictional conflict. In the wake of the recent financial crisis, there is an even greater consensus among countries that cooperation and reform are needed in the area of financial regulation. ${ }^{134}$ Because the Supreme Court's opinion in Morrison has the potential to leave significant groups of shareholders without an adequate remedy when harmed by transnational securities fraud, it may spur a recognition of the urgent need for greater global cooperation on the issue.

\section{B. The Supreme Court Embraces a Transaction-Based Test}

The foregoing policy considerations underlying the Supreme Court's decision in Morrison all raise the issue of the optimal level of antifraud regulation in transnational securities transactions. The Court's opinion seems

130 See id.

131 TeChNICAL COMM. OF THE INT'L ORG. OF SEC. COMM'NS, INT'L ORG. OF SEC. COMM'NS, Strengthening CAPITAL Markets AGaINST FinanCial FraUd ii (Feb. 2005), http://www.iosco.org/library/pubdocs/pdf/IOSCOPD192.pdf [hereinafter IOSCO REPORT]; see also Ana Carvajal \& Jennifer Elliott, The Challenge of Enforcement in Securities Markets: Mission Impossible? 6-11 (Int'l Monetary Fund, Working Paper No. $09 / 168$ 2009), available http://papers.ssm.com/sol3/papers.cfm?abstract_id=1457591 \&rec=1\&srcabs=1428899.

132 INST. OF INTERNAL AUdITORS ET AL., MANAGING THE BuSINESS RISK OF FraUd: A PractiCAL GUIDE 11 (2008), http://www.acfe.com/documents/managing-businessrisk.pdf.

133 For example, compare Rule 10b-5 with other antifraud regulations: Council Directive 2003/6, art. 1, 2003 O.J. (L 96) 20 (EC) (European Community regulation), and Australian Trade Practices Act of $1974 \S 52$. See also Sanzhu Zhu, Civil Litigation Arising from False Statements on China's Securities Market, 31 N.C. J. INT'L L. \& CoM. REG. 377, 378-79 (2005).

134 This has been a major topic of discussion among world leaders at the Group of 20 talks. Matt Spetalnick, Financial Regulation Rises to Top of G20 Agenda, REUTERS (Sept. 19, 2009, 3:09 PM), http://www.reuters.com/article/idUSTRE58G34Z20090919. 
to embrace a view expressed by scholars in recent years who support an exchange-based choice-of-law rule for securities fraud class action suits. Such commentators urge the creation of a rule under which foreign investors transacting on a non-U.S. exchange would be barred from bringing a $10 \mathrm{~b}-5$ claim in U.S. courts against the issuer. ${ }^{135}$ This approach takes the view that governments should only be concerned about regulating conduct that has effects on persons within their jurisdictions. ${ }^{136}$ Advocates of this rule focus on the effects of an alleged fraud, and assert that the conduct test, which is the basis of foreign-cubed claims, is not relevant because it has no bearing on the impact of behavior on welfare. ${ }^{137}$ The best way to maximize global welfare, on this view, is to rely on the market to select the optimal level of regulation. ${ }^{138}$

This exchange-based rule, which is close to the test articulated by Justice Scalia in the Court's opinion, ${ }^{139}$ would provide a number of benefits. First, it would provide issuers with valuable certainty as to the applicable law and reduce the incidence of jurisdictional conflict with other regulators. Such certainty would theoretically reduce the costs associated with offering securities and therefore allow the securities to be sold at a better price to investors. ${ }^{140}$ Second, this approach would theoretically lead to a socially

135 See, e.g., Choi \& Guzman, supra note 30 , at 240-41; Guzman, supra note 128, at 906-07.

136 See Guzman, supra note 128 , at 894.

$137 \mathrm{Id}$. at 921.

138 See id. at $921-25$.

139 While Justice Scalia clearly embraced the policy argument of commentators such as Professor Guzman, it is not entirely clear from the wording of the test if a strict transactional test is in fact the rule adopted by the Supreme Court. See Morrison v. Nat'1 Austl. Bank, 130 S. Ct. 2869, 2884 (2010); see also infra notes 156-67 and accompanying text. However, most courts and commentators have thus far interpreted the Morrison holding to impose a strict transaction-based test. See, e.g., In re Société Générale Sec. Litig., No. 08 Civ. 2495(RMB), 2010 WL 3910286, at *4 (S.D.N.Y. Sept. 29,2010 ).

140 No empirical proof of this theory is readily available. Furthermore, it is not clear to what extent the lurking threat of $10 \mathrm{~b}-5$ liability adds to the cost of securities for shareholders (in fact it may reduce it, if shareholders, in making their purchases, rely on the recovery available to them under $10 \mathrm{~b}-5$ in the event they are defrauded); rather, the theory is premised on the idea that the rule would lead to selecting a regulatory regime in regards to all aspects of securities regulation, such as, for example, the disclosure and reporting requirements, which more obviously correlate to a higher cost of securities for investors. In addition, not all issuers engage in fraud, so the choice of the optimal level of regulation by those who do not should not be affected by calculations of potential fraud liability. 
optimal level of regulation. ${ }^{141}$ If issuers choose to offer their securities on exchanges where investors perceive they will not receive adequate protection, investors will offer less for the securities than the issuer could obtain on an exchange associated with more investor-friendly rules. Conversely, under regimes where the marginal cost of additional regulations would outweigh the marginal benefits of the higher price investors might be willing to pay, issuers will not choose to sell there. ${ }^{142}$

Elsewhere, I have noted three problems with the exchange-based rule articulated above, as it relates to securities fraud regulation, that likewise are applicable to the Supreme Court's transactional test. ${ }^{143}$ I reiterate those problems here: The first problem is that the approach ignores the interconnectedness of the financial markets and the resulting interest of governments in punishing fraud, regardless of who is directly harmed. Fraud in one place can have a chilling effect on markets worldwide, and even investors and markets not directly affected by a fraud can be harmed indirectly by fraudulent activity elsewhere. ${ }^{144}$ This means that the U.S. and other countries have a strong interest in deterring fraud, regardless of where the effects are felt. Excluding foreign claimants from bringing suit in the United States, or from participating in class actions in the United States that are premised on the same underlying transaction in which the foreign claimants were harmed, undermines the deterrent effect of the private cause of action under Rule 10b-5.145 The benefits of the private cause of action, and the class action lawsuit in particular, are not available in most other countries, which "'lack private procedural instruments which can generate rigorous substantive control.""146

A second problem with the market-based approach to fraud regulation is that it ignores other factors influencing the choice of law (or here, the selection of a market). This calls into question the underlying assumption of the theory that "choice" will lead to a socially optimal level of regulation. In

141 See, e.g., Merritt B. Fox, Retaining Mandatory Securities Disclosure: Why Issuer Choice is Not Investor Empowerment, 85 VA. L. REV. 1335, 1337-38 (1999).

142 Guzman, supra note 128 , at 914 .

143 See Beyea, supra note 128.

144 See IOSCO REPORT, supra note 131, at ii (noting that the concerns raised by financial scandals involving large, publicly-traded companies are "truly global in nature").

145 See Ilana T. Buschkin, Note, The Viability of Class Action Lawsuits in a Globalized Economy-Permitting Foreign Claimants to Be Members of Class Action Lawsuits in the U.S. Federal Courts, 90 CORNELL L. REV. 1563, 1588 (2005).

${ }^{146} \mathrm{Id}$. (quoting Richard B. Cappalli \& Claudio Consolo, Class Actions for Continental Europe? A Preliminary Inquiry, 6 TEMP. INT'L \& COMP. L.J. 217, 267-68 (1992)). 
practice there are many factors besides antifraud protections that dictate where people invest and where issuers choose to sell their securities, including tax considerations, expertise of regulators, reporting requirements, and even simple geography. All other things being equal, the law and economics approach to antifraud regulation might be a good one, but unfortunately, all other things are not equal. ${ }^{147}$ Therefore, market selection may not in fact lead to the optimal level of antifraud protection. A marketbased approach may in fact lead to a regulatory "race to the bottom."148 Related to this is the law-and-economics assumption of the rational investor, which holds that investors price the potential for fraud into the securities they purchase. This assumption implies that if issuers choose a regime perceived as not adequately deterring or punishing fraud, they will receive a lower price for their shares, which will point issuers towards listing where strong antifraud protection exists. However, the assumptions associated with the rational investor model do not necessarily hold up under scrutiny. An alternative model of investor behavior, the so-called "trusting investor" model, ${ }^{149}$ argues that investors "are willing to lose fair and square but not to be taken by fraud." 150 After they are defrauded, investors lose trust in the markets, leading to price declines and potentially prolonging a bear market. ${ }^{151}$ While it is unclear which view of investor behavior has been empirically proven, there is at least some evidence that a significant number of investors better fit the trusting investor model. ${ }^{152}$ This evidence against the rational investor model, combined with the potential for a regulatory race-tothe-bottom, ${ }^{153}$ both caution against letting the markets decide the appropriate level of antifraud regulation.

Third, for the transaction-based approach articulated by the Supreme Court to adequately protect defrauded U.S. investors, one must assume that all other countries with a stock exchange have an adequate antifraud

147 See Paul B. Stephan, The Political Economy of Choice of Law, 90 GEO L.J. 957, 959 (2002).

148 The race-to-the-bottom versus race-to-the-top debate has recurred throughout corporate legal scholarship. See, e.g., Lucian Arye Bebchuk \& Alma Cohen, Firms' Decisions Where to Incorporate, 46 J. L. \& ECON. 383, 384 \& n.1 (2003).

149 See Lynn A. Stout, The Ninth Annual Abraham L. Pomerantz Lecture: The Investor Confidence Game, 68 BROOK. L. REV. 407, 415-20 (2002).

150 Tamar Frankel, The Ninth Annual Abraham L. Pomerantz Lecture: Regulation and Investors' Trust in the Securities Markets, 68 BROOK. L. REV. 439, 443 n.17 (2002).

151 Stout, supra note 149, at 436.

152 See generally id.

153 See Fox, supra note 141, at 1394-95 (arguing against a market-based, issuer choice regime in the context of disclosure regulations, due to the likelihood that issuers will choose a regulatory regime with less-than-optimal disclosure requirements). 
enforcement regime. Such an assumption may be true in respect to some countries but certainly not all of them. Even countries with advanced financial systems such as Germany have recently been reexamining their securities enforcement systems following large corporate scandals. ${ }^{154}$ The Securities and Exchange Commission has argued against the market-based approach for this reason, fearing it would let too much fraud slip through the cracks. ${ }^{155}$ Of course, the reasoning in the Supreme Court's decision relied primarily on the text of the statute, and therefore did not leave room for the countervailing policy considerations that weigh in favor of a more flexible rule than the one adopted by the Court in this case. However, the potential impact of the Morrison decision may be ameliorated somewhat by actions taken by Congress and the SEC. ${ }^{156}$

\section{Implications of the Court's Opinion on Specific Constituencies: Dual-and Cross-Listed Companies and U.S. Investors Purchasing Shares in Foreign Companies}

Although the Court's vision as to the proper extraterritorial reach of the securities laws is quite clear from Justice Scalia's opinion, upon closer examination, the actual holding of the case raises a number of questions that will bear on its application to future cases. The Court calls its new test a transactional test. ${ }^{157}$ The implication is that application of $10(\mathrm{~b})$ will be premised on the location of the transaction. However, the holding of the case does not actually say that. Justice Scalia's test states simply that 10(b) applies "only [to] transactions in securities listed on domestic exchanges, and domestic transactions in other securities." 158 Does this mean Section 10(b) will apply to all transactions in securities listed on domestic exchanges, regardless of where the transactions occur? As for the second prong, how will courts define a "domestic transaction in other securities"? Answers to these questions will have important direct impacts on a number of specific constituencies, namely dual- and cross-listed companies, and U.S. residents who invest directly in foreign companies.

154 See Astrid Stadler, A Test Case in Germany: 16,000 Private Investors vs. Deutsche Telekom, 10 ERA FORUM 37, 37-48 (2009) (discussing recent German reforms to its securities laws act aimed at coping with mass litigation in German courts).

155 SEC Brief, supra note 5, at 27-28.

156 See discussion infra Part V.A.

157 Morrison v. Nat'l Austl. Bank, 130 S. Ct. 2869, 2886 (2010).

158 Id. at 2884 . 
For cross-listed and dual-listed companies, ${ }^{159}$ how the Court's holding is interpreted will have important consequences for their future Section 10(b) liability. Reading the holding in the context of the dicta in the rest of the opinion, it certainly seems that the Court intended Section 10(b) to apply only to domestic transactions in securities traded on a domestic exchange (or other domestic transactions), but that transactions on a foreign exchange, even if the same securities involved in such foreign transactions were also listed on a U.S. exchange, would not be subject to Section 10(b). However, it would have been very easy to write a holding that clearly stated such a rule. The simple addition of the word "domestic" before the phrase "transactions in securities listed on domestic exchanges" 160 would have accomplished this. A number of amici also suggested alternative rules that would have established a truly transactional test, ${ }^{161}$ and commentators have been articulating exchange-based tests for years. ${ }^{162}$

A literal reading of the language of the holding implies that even if a foreign company issues misleading statements overseas to primarily foreign investors, if the stock about which the misleading statements were made is also listed on a U.S. exchange, Section 10(b) will apply. The reference to "securities listed on domestic exchanges" was repeated three times in the opinion, ${ }^{163}$ which logically implies that Justice Scalia meant what he said. In addition, the opinion's emphasis on protecting domestic exchanges supports this outcome, because if the securities are listed on a domestic exchange, fraud related to a particular class of securities, no matter where the plaintiffs in question purchased their securities, will have an effect on the price of those securities on the domestic exchange. ${ }^{164}$ The Exchange Act seems to

159 Cross-listed companies' shares trade primarily on a local exchange, but are also traded in a secondary listing on an exchange in another country, generally in the form of depositary receipts. (If the secondary listing is in the U.S., for example, these will be American Depositary Receipts.) Dual-listed companies have their shares directly listed on multiple stock exchanges.

160 Morrison, $130 \mathrm{~S}$. Ct. at 2884.

161 See, e.g., Brief of Amici Curiae Law Professors in Support of Respondents at 31, Morrison, 130 S. Ct. 2869 (No. 08-1191) (arguing for a bright-line rule under which Section 10(b) would only apply to securities bought or sold in the United States).

162 See, e.g., Choi \& Silberman, supra note 41, at 492-93.

163 Morrison, $130 \mathrm{~S}$. Ct. at $2884,2885,2886$. The formulation on page 2885 of the opinion uses the term "national securities exchanges."

164 While it is indisputable that a "domestic effect" will occur in such a scenario, because the price of the shares will generally fall on all exchanges upon which they are traded, this alone will not necessarily give rise to a claim under Section 10(b) for foreign plaintiffs who did not purchase their securities on a U.S. exchange. See Choi \& Silberman, supra note 41 , at 476 . Furthermore, U.S. courts have traditionaily declined to 
implicitly recognize this in the portion of its preamble cited by the petitioners as textual evidence of the Act's extraterritorial application. ${ }^{165}$ Though the Court dismissed this argument, and while it is not the kind of clear statement of extraterritorial application that would have been conclusive of Congress's intent, it does recognize the U.S. interest expressed by the Second Circuit in Schoenbaum v. Firstbrook ${ }^{166}$ when it held that Section 10(b) would apply to "violations of the [Exchange Act] although the transactions which are alleged to violate the Act take place outside the United States, at least when the transactions involve stock registered and listed on a national securities exchange, and are detrimental to the interests of American investors."167 This expression of U.S. interest could support a literal reading of the first prong of the Court's Morrison holding, that Section 10(b) will apply to a fraudulent transaction whenever the stock at issue is listed on a national exchange.

The Court's application of the holding to the facts of Morrison also supports this view. In concluding that the petitioners had failed to state a claim, Justice Scalia wrote, "This case involves no securities listed on a domestic exchange, and all aspects of the purchases complained of by those petitioners . . o occurred outside the United States."168 Inclusion of the first clause of this sentence implies that if the securities in question had been listed on a domestic exchange, the outcome would have been different. If the Court had intended a purely transactional test, it would have been sufficient to state only that "the purchases . . occurred outside the United States."

However, this reading of the Court's decision presents a problem on the facts of the case: National Australia Bank had American Depositary Receipts (ADRs) ${ }^{169}$ trading on the New York Stock Exchange. Not all ADRs traded in

apply Section 10(b) to foreign plaintiffs on the basis of such an argument under the effects test. These courts have held that, even though the same foreign conduct may have caused harm to U.S. resident holders of a company's securities (e.g., in the form of ADRs) and to foreign purchasers of the securities, jurisdiction does not extend to the foreign plaintiffs' claims under the effects test (though the U.S. purchasers would have a claim under Section 10(b) on the basis of the effects test). See, e.g., In re Baan Co. Sec. Litig., 103 F. Supp. 2d 1, 11 \& n.16 (D.D.C. 2000).

165 Brief for Petitioners, supra note 95, at 39 (citing 15 U.S.C. $\$ 78 b(2)$ (2006)).

166405 F.2d 200 (2d Cir. 1968).

167 Id. at 208 (citations omitted).

168 Morrison, 130 S. Ct. at 2888.

169 "The ADR, similar in form to a standard U.S. registered stock certificate, is a substitute trading certificate evidencing the ADSs that represent the underlying shares of the foreign corporation." CLEARY GOTTLIEB STEEN \& HAMILTON LLP, GUIDE TO PUBLIC ADR OFFERINGS IN THE UNITED STATES 3 (Apr. 15, 2007) [hereinafter GUIDE TO ADR OFFERINGS], http://www.cgsh.com/nl-

NU/guide_to_public_adr_offerings_in_the_united_states/. "ADSs" are American Depositary Shares. See id. at 1. 
the United States are also "listed" on an exchange, 170 but the Court's own opinion states that NAB's ADRs were "listed on the New York Stock Exchange."171 Either the Court overlooked this, or it did not understand the relevance of this fact. If a company lists ADRs on a national stock exchange, the ADRs (representing American Depositary Shares, or ADSs) must be registered with the Securities and Exchange Commission pursuant to Section 12(b) of the Exchange Act, ${ }^{172}$ and the registration process typically involves the registration of two securities: the underlying shares and the ADSs themselves. ${ }^{173}$ In addition, ordinary shares underlying the listed ADRs are technically also listed on the exchange. ${ }^{174}$ This renders inaccurate the Court's statement that the securities at issue in Morrison were not registered on a domestic exchange, since technically the NAB common stock underlying the

170 There are three "levels" of American Depositary Receipt programs. Levels 2 and 3 ADRs are listed on a domestic exchange, whereas Level 1 ADRs trade over-thecounter. Id. at $9 \mathrm{n} .23$. One recent post-Morrison district court opinion declined to apply Rule $10 \mathrm{~b}-5$ to the claims of U.S. purchasers of Level 1 ADRs in U.S. over-the-counter transactions. In re Société Générale Sec. Litig., No. 08 Civ. 2495(RMB), 2010 WL 3910286 , at *6 (S.D.N.Y. Sept. 29, 2010). However, this holding itself is questionable for a number of reasons. First of all, the court's opinion evinces a poor understanding of transactions in ADRs. These transactions are a way in which foreign issuers can avail themselves of the U.S. markets, but the transactions, whether over-the-counter or on a market, clearly take place in the United States. Traditionally, issuers of ADRs in the U.S. understood that they may be subject to 10b-5 liability. See Establishing a Level 1

American Depositary Receipt Program, NORTON ROSE LLP (July 2009), http://www.nortonrose.com/knowledge/publications/2009/pub22176.aspx?page $=0907231$ 71010\&lang=en-gb. Secondly, the court in Société Générale relied on a misplaced quote from another case, In re SCOR Holding (Switzerland) AG Litigation, where the court in dicta that was specific to the facts of that case stated, "Assuming that the purchase of ... ADSs on the NYSE and the purchase of . . shares by U.S. residents on the [Swiss Stock Exchange] may be viewed as predominantly foreign securities transactions ...." $537 \mathrm{~F}$. Supp. 2d 556, 561 (S.D.N.Y. 2008) (footnote omitted). On the basis of this quote, taken out of context, the judge in Société Générale asserted that "[t]rade in ADRs is considered to be a predominantly foreign securities transaction." 2010 WL 3910286 , at *4 (citations omitted) (internal quotation marks omitted). Under the second prong of the Supreme Court's holding in Morrison, there is no reason to believe that Section 10(b) should not apply to purchases by U.S. persons of Level 1 ADRs which are sold in over-the-counter transactions in the United States.

171 Morrison, $130 \mathrm{~S}$. Ct. at 2875.

17215 U.S.C. $\S 78 l(\mathrm{~b})(2006)$.

173 GUIDE TO ADR OFFERINGS, supra note 169 , at 9.

174 Vivendi III, No. 02 Civ. 05571(RJH)(HBJ), 2011 WL 590915, at *7 n.13 (S.D.N.Y. Feb. 17, 2011). 
ADRs was listed on the NYSE. ${ }^{175}$ A number of recent district court opinions addressing the application of Section 10(b) to transactions in ADRs show a failure to understand the nature of ADR programs, barring the claims of U.S. plaintiffs who purchased the ADRs of foreign-listed companies in the United States. ${ }^{176}$ This failure to grasp the fact that Levels 2 and 3 ADRs are in fact listed on U.S. exchanges may also have been the Supreme Court's problem in rendering its opinion in Morrison, or it could have been a simple mistake in drafting the opinion so that it is less clear in stating a transactional test than the Court intended. 177

How other courts interpret the Morrison holding in light of the foregoing will have a significant bearing on the outcome of a number of transnational securities fraud cases currently going forward in U.S. courts. The In re Vivendi Universal securities litigation has been progressing through U.S. courts since $2002,{ }^{178}$ following the issuance of material misrepresentations about the French company's severe cash crisis in the wake of some highprofile acquisitions in the U.S. and Canada. ${ }^{179}$ In October 2009, the case actually went to trial, and the jury returned a verdict in February 2010 finding the company liable for misleading investors. ${ }^{180}$ Following the jury verdict, it was estimated that the claims against Vivendi could total as much

17517 C.F.R. $\$ 240.12 \mathrm{dl}-1$ (2010). The court also used the terms "listed" and "registered" interchangeably, see, e.g., Morrison, $130 \mathrm{~S}$. Ct. at 2885 , though there is a technical difference in the meaning of the terms.

176 See, e.g., In re Société Générale Sec. Litig., No. 08 Civ. 2495(RMB), 2010 WL 3910286, at *4 (S.D.N.Y. Sept. 29, 2010); Copeland v. Fortis, 685 F. Supp. 2d 498, 506 (S.D.N.Y. 2010); In re SCOR Holding (Switz.) AG Litig., 537 F. Supp. 2d 556, 562 (S.D.N.Y. 2008).

${ }^{177}$ It is also possible that the Supreme Court intended to bar the claims of plaintiffs who had purchased U.S.-listed ADRs in the United States; however, this would be a somewhat radical result, as ADRs (at least Levels 2 and 3 programs) heretofore have clearly been covered by U.S. securities laws. See, e.g., International Investing, U.S. SEC. AND EXCH. COMM'N, http://www.sec.gov/investor/pubs/ininvest.htm (last visited Jan. 16, 2011) ("When you buy and sell ADRs you are trading in the U.S. market."). This would appear to be a re-writing of the securities laws, if it is in fact what the Supreme Court intended. The more likely explanation for the lower court decisions is that lower courts are simply misconstruing Morrison in applying it to dismiss the claims of U.S. purchasers who bought ADRs in the United States.

178 See Vivendi II, No. 02 Civ. 5571(RJH), 2004 WL 2375830, at *1 (S.D.N.Y. Oct. 22, 2004).

179 See Vivendi I, 381 F. Supp. 2d 158, 166-69 (S.D.N.Y. 2003).

180 Grant McCool, Vivendi Faces Damages, to Appeal Jury Verdict, ReUTERS (Jan. 29, 2010, 3:16 PM), http://www.reuters.com/article/idUSTRE60S5VU20100129. 
as four billion dollars. ${ }^{181}$ However, Vivendi appealed the verdict on the basis of the Supreme Court's decision in Morrison. ${ }^{182}$ Attorneys for the Vivendi shareholders argued that because at least some of Vivendi's ordinary shares and its ADRs - the two classes of shares covered by the jury verdict-were listed on the NYSE, and because the ordinary shares were registered with the SEC pursuant to Section 12(b) of the Exchange Act, Morrison should not affect the foreign plaintiffs' ability to proceed in the case. ${ }^{183}$ However, in ruling on the appeal, the court found that the plaintiffs' argument failed on a technicality: "registration with the SEC is not the same as listing (registering) on an exchange," the court noted. ${ }^{184}$ Furthermore,

[t] the sample NYSE listing application provided to the Court at argument indicates that only a discrete number of ordinary shares are listed; this being the number of ordinary shares needed to back-up the ADRs being listed. Thus while all ordinary shares of a foreign issuer are deemed to be registered with the SEC, a lesser fixed amount of shares are actually listed with the Exchange. And ordinary shares that are not listed on an exchange (for any purpose) would fall outside plaintiffs' literalist reading of the Morrison bright-line test as well as the underlying language of Section $10\left(\right.$ b) ${ }^{185}$

This decision in the Vivendi litigation thus limits recovery to plaintiffs (both domestic and foreign) who actually purchased ADRs on the NYSE, and excludes the claims of plaintiffs who purchased ordinary shares of Vivendi Universal on foreign exchanges. This is a reasonable reading of the Morrison decision, and a considerable improvement on other post-Morrison district court decisions such as In re Société Générale. ${ }^{186}$ However, it now leaves a significant group of foreign Vivendi investors without a remedy. In

181 Id.; but see Vivendi Liable, supra note 48 ("[T] he potential payout could total $\$ 9.3$ billion."). Following Judge Holwell's 2011 decision narrowing the class of claimants to only certain purchasers of the ADRs, the total amount of liability will be significantly reduced. See Vivendi Universal, S.A.: American Depositary Receipts, STANFORD LAW SCHOOL SECURITIES Class ACTION Clearinghouse, http://securities.stanford.edu/1024/V02-01/ (last visited Mar. 16, 2011) (noting that the decision eliminates more than eighty percent of the potential damages in the case).

182 See Vivendi III, No. 02 Civ. 05571(RJH)(HBJ), 2011 WL 590915, at *4 (S.D.N.Y. Feb. 17, 2011).

183 Id.; see also Jonathan Stempel, Vivendi Argues for Dismissal of a Jury Verdict, REUTERS (July 26, 2010, 1:57 PM), http://www.reuters.com/article/2010/07/26/usvivendi-hearing-idUSTRE66P4SF20100726.

184 Vivendi III, 2011 WL 590915, at *8.

$185 \mathrm{Id}$.

186 See supra notes $176-77$ and accompanying text. 
addition to the Vivendi litigation, the outcomes of a number of cases filed by British Petroleum shareholders against that company in relation to alleged misrepresentations about the Deepwater Horizon rig could also be affected by the Morrison decision.

The outcomes of those cases will have an important impact for crosslisted companies with ADRs trading in the United States. This is no small matter, as ADRs are currently the most common way that foreign companies list and offer equity securities in the United States. ${ }^{187}$ These cases may also affect dual-listed companies that list the same class of their common stock on both a U.S. and a foreign exchange, which face a similar fact pattern to crosslisted companies in the context of their Section 10(b) liability. While duallisted companies are clearly subject to Section 10(b) liability with respect to material misrepresentations or omissions in connection with the securities listed on a U.S. exchange, an expansive interpretation of the first prong of the Supreme Court's holding in Morrison could expand the scope of their liability to include foreign investors who purchased securities abroad. A literal reading of the holding raises this possibility. However, such foreign plaintiffs' claims would not have survived under the old effects test absent significant domestic conduct that would fulfill the conduct test, ${ }^{188}$ and Morrison clearly narrowed the extraterritorial application of the securities laws from the previous state of affairs under the old conduct and effects tests. Therefore, it seems unlikely that courts will interpret the Morrison holding this way. However, until subsequent court decisions clarify this, cross-listed and dual-listed companies cannot yet breathe a sigh of relief.

Though the facts of Morrison only implicated the conduct test, the Supreme Court's new "transactional test" also reaches factual situations that previously would have been dealt with under the Second Circuit's effects test. Therefore, a third constituency that will be directly impacted by the Court's holding in Morrison is U.S. investors who purchase shares overseas. This includes, for example, U.S.-based mutual or pension funds that purchase shares directly on foreign exchanges, but in the modern era this could also be a relatively unsophisticated U.S. investor who purchases shares in a foreign company online from his local coffee shop through the services of an online brokerage firm. Prior to Morrison, it was well-settled law that American purchasers of a foreign company's shares could bring claims under Rule 10b-5. 189 The first prong of the Supreme Court's holding now clearly bars such an investor from raising $10 \mathrm{~b}-5$ claims so long as the particular shares

187 GUIDE TO ADR OFFERINGS, supra note 169, at 2.

188 Choi \& Silberman, supra note 41 , at 476.

189 See Vivendi III, 2011 WL 590915, at *9 (citing Morrison v. Nat'l Austl. Bank, 130 S. Ct. 2869, 2895 (Stevens, J., concurring)). 
are not also listed on a domestic exchange. Whether or not such an investor could raise a claim under the second prong of the test, which refers to "domestic transactions in other securities," is less clear.

The most obvious scenario to which the second prong applies is, for example, transactions carried out under Regulation D, whereby a foreign issuer carries out a private placement in the United States. Securities sold in this manner are exempt from the registration requirements of Section 5 of the Securities Act and are not listed on an exchange, 190 but presumably the issuer would still be subject to Rule 10b-5 liability as these are clearly considered domestic transactions. ${ }^{191}$ Whether or not it applies to investors who purchase shares directly on foreign exchanges (whether through a broker or otherwise) will most likely be determined by subsequent judicial decisions.

At least two post-Morrison decisions by a lower court suggest that the answer is still no. In Cornwell v. Credit Suisse Group, 192 U.S. resident plaintiffs who had purchased shares of defendant Credit Suisse directly on the Swiss Stock Exchange asserted that Morrison did not prevent them from maintaining their Section 10(b) claims. ${ }^{193}$ The district court resoundingly rejected the plaintiffs' argument, stating, "This Court is not convinced that the Supreme Court designed Morrison to be squeezed, as in spandex, only into the factual strait jacket of its holding."194 Reading the Supreme Court case as a whole, the district court found the opinion indicated "that the Court considered that under its new test Section 10(b) would not extend to foreign securities trades executed on foreign exchanges even if purchased or sold by American investors." 195 Similarly, in the most recent opinion in the Vivendi litigation, Judge Holwell held that American purchasers of Vivendi ordinary shares on a foreign exchange could not bring claims under Section 10(b). ${ }^{196}$ This reading of the Morrison decision is not surprising, and probably sets the trend that will be followed by lower courts in ruling on claims brought by U.S. plaintiffs who purchased shares on foreign exchanges.

19017 C.F.R. $\S \S 230.504-.506$ (2010).

191 Stephen Choi, Assessing the Cost of Regulatory Protections: Evidence on the Decision to Sell Securities Outside the United States 3 (Yale Law Sch. John M. Olin Ctr. for Studies in Law, Econ., \& Pub. Policy, Working Paper No. 253, 2001), available at http://papers.ssrn.com/sol3/papers.cfm?abstract_id=267506.

192729 F. Supp. 2d 620 (S.D.N.Y. 2010).

193 Id. at 621-22. The claims of a number of investors who had purchased Credit Suisse ADRs on the New York Stock Exchange were not addressed in the opinion and presumably are still live claims.

$194 \mathrm{Id}$. at 625.

195 Id. at 625-26.

196 Vivendi III, No. 02 Civ. 05571(RJH)(HBJ), 2011 WL 590915, at *10 (S.D.N.Y. Feb. 17, 2011). 
Assuming that courts construe Morrison as the Cornwell and Vivendi courts did, Morrison will have the effect of narrowing the effects test to exclude U.S. investors who purchased their shares on foreign exchanges. This could potentially make domestic investors more wary of trading in foreign securities, since the protections of Section 10(b) may no longer be available to them. However, this may have the indirect benefit of encouraging foreign countries to improve their own antifraud regulations in the hopes of encouraging U.S. investors to invest in their markets.

\section{CONGRESSIONAL AND REgUlatory RESPONSES TO MORRISON}

\section{A. The Dodd-Frank Act}

Even before the Supreme Court began its consideration of Morrison $v$. National Australia Bank, Congress was already working to respond to the expected outcome. ${ }^{197}$ A bill passed the House of Representatives in December 2009 that was intended to codify the Second Circuit's test for extraterritorial application of Section 10(b). ${ }^{198}$ A revised version of these provisions, articulating the same test as the earlier House bill, but limiting its application to actions brought by the Commission only, was adopted by the whole Congress with passage of the Dodd-Frank Act less than a month after the Court's decision in Morrison. ${ }^{199}$ The Act also ordered the Commission to conduct a study to determine whether the same test for extraterritorial application should also extend to private rights of action. ${ }^{200}$ However, because the language of the Act was drafted prior to the decision (and apparently without consideration of the Solicitor General's amicus brief in the Morrison litigation), the Act may not actually have any effect, due to the Court's correction of the Second Circuit's "threshold error" in Morrison.

As discussed in Part II.D. of this Article, courts have traditionally addressed the question of the extraterritorial application of the securities laws as a question of subject matter jurisdiction. In accordance with this, the language of the Dodd-Frank Act states that U.S. district courts "shall have jurisdiction" over claims arising under the antifraud provisions of the Exchange Act whenever there is "(1) conduct within the United States that constitutes significant steps in furtherance of the violation, even if the securities transaction occurs outside the United States and involves only foreign investors; or (2) conduct occurring outside the United States that has

197 Dodd-Frank Act, H.R. 4173, 11 lth Cong. $§ 7216$ (2009).

198 Id. $\S 7216$ (b).

199 Dodd-Frank Act, Pub. L. No. 111-203, § 929P, 124 Stat. 1376, 1862 (2010).

200 Id. $\S 929 \mathrm{Y}$. 
a foreseeable substantial effect within the United States."201 A number of recent Supreme Court cases preceding Morrison had chastised the lower courts for their "less than meticulous" treatment of the distinction between an element of a claim for relief under federal law and a limitation on subject matter jurisdiction. ${ }^{202}$ In recognition of this, the Solicitor General in her amicus brief to the Supreme Court in the Morrison case pointed out the problem and urged that the Court should treat the question of extraterritorial application as a question of a plaintiff's entitlement to relief under the relevant provisions of the Exchange Act. ${ }^{203}$ However, though the Solicitor General's brief was submitted before the House passed its version of the Dodd-Frank Act, the drafters of the bill either did not take note of the point or were unaware of its significance for the language of the Act. In its opinion in Morrison, the Supreme Court did correct this "threshold error" in the Second Circuit's approach to extraterritorial application of Section 10(b), effectively rendering moot the language of the Dodd-Frank Act, since the federal courts already have jurisdiction under Section 27 of the Exchange Act. 204

While Congress's intent in including this language was clearly to preserve the conduct and effects tests, the language of the Act as drafted does not actually do so. The Supreme Court in Morrison acknowledged that federal courts have subject matter jurisdiction over such cases, but held that Section 10(b) would not apply to transactions that did not meet its test. ${ }^{205}$ Therefore, the Dodd-Frank Act may not have any effect on the application of Section 10(b), depending on the willingness of courts to overlook the plain language of the statute, even if this language is the result of a simple drafting error. In light of this, and because Section 929Y of the Act instructs the SEC to commission a study on extraterritorial application of Section 10(b) in private rights of action, further pronouncements from Congress and the Commission may be forthcoming. Though the Commission sided with the Morrison respondents in its amicus brief to the Supreme Court in the case, it had cautioned against too severe a restriction on extraterritorial application of Section 10 (b). ${ }^{206}$ The Commission, therefore, is more likely than not to

201 Id. $\S 929 \mathrm{P}(\mathrm{c})$.

202 See, e.g., Arbaugh v. Y \& H Corp., 546 U.S. 500, 511 (2006).

${ }^{203}$ Brief for the United States as Amicus Curiae Supporting Respondents, supra note 99 , at 9.

${ }^{204}$ Morrison v. Nat'l Austl. Bank, 130 S. Ct. 2869, 2876-77 (2010) (citing 15 U.S.C. § 78aa (2006)).

$205 \mathrm{Id}$. at 2877.

206 See id. at 2882. 
respond to its mandate from Congress in favor of a more flexible test for extraterritorial application of Section $10(\mathrm{~b})$ in private rights of action.

\section{B. Possible Securities and Exchange Commission Responses to Morrison v. National Australia Bank}

The Supreme Court's opinion in Morrison practically invites the Commission to begin a round of rulemaking under Section 30(b) of the Exchange Act. In determining that the presumption against extraterritoriality should apply to claims arising under Section 10(b) of the Exchange Act, the Court focused on the language of Section 30(b) of the Act. Section 30(b) "specifies that the [Exchange] Act does not apply to "any person insofar as he transacts a business in securities without the jurisdiction of the United States,' unless he does so in violation of regulations promulgated by the Commission 'to prevent evasion [of the Act]."207 The Court interpreted this to mean that foreign transactions were not within the scope of the Exchange Act, "absent regulations by the Commission."208

This opens up the door for the Commission, should it so opt, to draft regulations extending the scope of the Act to some foreign transactions. Of course, such regulations would have to be within the mandate given to the Commission by Congress, and thus limited to regulations the Commission deems necessary to "prevent the evasion of [the Exchange Act]."209 What exactly such regulations would look like is not clear, since the Commission has never taken advantage of this provision. However, the Court's opinion provides some guidance, stating that " $[t]$ he provision seems to us directed at actions abroad that might conceal a domestic violation, or might cause what would otherwise be a domestic violation to escape on a technicality." 210 The Commission could thus draft a regulation that would make the antifraud provisions of the Exchange Act apply, for example, to the purchase by a U.S. citizen, through a Canadian brokerage house, of securities listed only on the Toronto Stock Exchange, where the defendant had only minimal contacts with the United States. ${ }^{211}$ Whether or not the SEC will choose to go down this route remains to be seen.

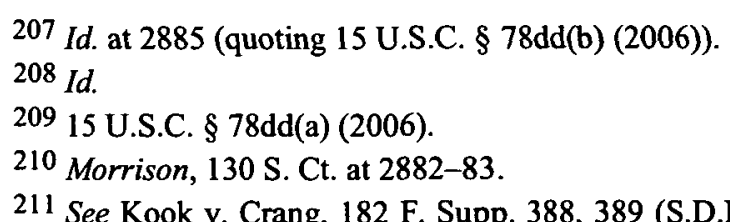
Goldman \& Joseph L. Magrino, Jr., Some Foreign Aspects of Securities Regulation: Towards a Reevaluation of Section 30(b) of the Securities Exchange Act of 1934, 55 VA. 
An additional step that should be taken by the Commission is a clarification of the nature of American Depositary Receipt programs. At the very least, the Commission should address this issue in its report to Congress, given the recent erroneous decisions by district courts, applying Morrison to dismiss the claims of U.S. plaintiffs who have purchased ADRs of foreign companies on a U.S. exchange.

\section{CONCLUSION}

The Supreme Court's opinion in Morrison v. National Australia Bank represents a significant departure from courts' longstanding approach to deciding when the securities laws apply in cases involving transnational securities fraud. In articulating a new transactional test, the Court takes another step towards "render[ing] the private cause of action under $\S 10(b)$ toothless," 212 arguably the most important anti-fraud provision in the U.S. securities laws. This carries important implications for regulation of securities fraud, at least in the short term, increasing the potential that more transnational securities fraud will go unpunished, and possibly also underdeterring such fraud. It also leaves a number of questions as to its application for plaintiffs who purchase shares in companies with American Depositary Receipts listed on U.S. markets or in dual-listed companies. The outcome of a number of major transnational securities fraud cases currently in U.S. district courts will depend on answers to these questions. In the longer term, the opinion invites reaction from both Congress and the Securities and Exchange Commission, either in the form of a clear pronouncement from Congress about the extraterritorial reach of the securities laws, or in the form of new regulations from the Commission that could close some loopholes for companies that commit fraud affecting U.S. markets or investors but structure their transactions in such a way as to avoid application of U.S. law. ${ }^{213}$ In the Dodd-Frank Act, Congress did attempt to make a clear pronouncement that, at least where enforcement actions brought by the Commission are concerned, Section 10(b) may still be applied extraterritorially under the old tests articulated by the Second Circuit. ${ }^{214}$ Less than meticulous drafting of the Act, however, raises the specter that lower

L. REV. 1015, 1027 (1969) (noting that the factual situation in Kook was considered exactly the type of situation for which Section 30(b) had been enacted to address).

212 Morrison, $130 \mathrm{~S}$. Ct. at 2895 (Stevens, J., concurring in the judgment) (citing Stoneridge Inv. Partners, LLC v. Scientific-Atlanta, Inc., 552 U.S. 148, 175 (2008) (Stevens, J., dissenting)).

213 See supra Part V.

214 Dodd-Frank Act $§ 929 P$. 
courts will decline to interpret the Dodd-Frank Act as having any real effect on the extraterritorial application of the securities laws.

The Supreme Court's opinion in Morrison expresses skepticism over the benefits of private litigation in aid of enforcement of the securities laws. However, limiting the private right of action may do more harm than good at a time when investor confidence is already on shaky ground in the wake of the 2008 financial crisis. While issuers will generally applaud the decision because it provides increased certainty and limits their exposure to the U.S. securities antifraud provisions, it has been viewed as a step backwards by those who advocate for shareholder interests. ${ }^{215}$ However, while the decision may let more fraud slip through the cracks, in the best-case scenario it may also provide a catalyst for securities fraud enforcement reform in other countries, and for better cross-border cooperation in enforcement. 